\title{
Salinarimonas rosea gen. nov., sp. nov., a new member of the $\alpha-2$ subgroup of the Proteobacteria
}

\author{
Correspondence \\ Xiao-Long Cui \\ xlcuiynu@yahoo.com.cn or \\ xlcui@ynu.edu.cn
}

\author{
Ji-Hui Liu, ${ }^{1}+$ Yong-Xia Wang, ${ }^{1}+$ Xiao-Xia Zhang, ${ }^{2}$ Zhi-Gang Wang, ${ }^{1}$ \\ Yi-Guang Chen, ${ }^{1,3}$ Meng-Liang Wen, ${ }^{1}$ Li-Hua Xu, ${ }^{1}$ Oian Peng ${ }^{1}$ \\ and Xiao-Long Cui ${ }^{1}$
}

\author{
${ }^{1}$ Yunnan Institute of Microbiology, Yunnan University, Kunming, Yunnan 650091, PR China \\ ${ }^{2}$ Agricultural Cultural Collection of China, Institute of Agricultural Resources and Regional Planning, \\ Chinese Academy of Agricultural Sciences, Beijing 100080, PR China \\ ${ }^{3}$ College of Bio-resources and Environmental Science, Jishou University, Jishou, Hunan 416000, \\ PR China
}

\begin{abstract}
A Gram-negative, rod-shaped, facultatively anaerobic, halotolerant bacterial strain, designated YIM YD3 ${ }^{\top}$, was isolated from a salt mine in Yunnan, south-west China. The taxonomy of strain YIM YD3 ${ }^{\top}$ was investigated by a polyphasic approach. Strain YIM YD3 ${ }^{\top}$ was motile, formed pink colonies and was positive for catalase and oxidase activities. Q-10 was the predominant respiratory ubiquinone. The major polar lipids were diphosphatidylglycerol, phosphatidylglycerol, phosphatidylmethylethanolamine, phosphatidylcholine and two unknown phospholipids. The major fatty acids (>10\% of total fatty acids) were $\mathrm{C}_{18: 1} \omega 7 c, \mathrm{C}_{18: 1} \omega 9 c, \mathrm{C}_{16: 0}$ and $\mathrm{C}_{19: 0}$ cyclo $\omega 8 c$. The DNA G $+\mathrm{C}$ content was 71.8 mol\%. Phylogenetic analysis based on 16S rRNA gene sequence comparisons showed that the isolate formed a distinct line within a clade containing the genera Balneimonas, Bosea, Chelatococcus and Microvirga in the order Rhizobiales, with highest levels of 16S RNA gene sequence similarity to the type strain of Balneimonas flocculans $(93.5 \%)$. On the basis of phenotypic, chemotaxonomic and phylogenetic data, strain YIM YD3 ${ }^{\top}$ represents a novel species in a new genus, for which the name Salinarimonas rosea gen. nov., sp. nov. is proposed, with strain YIM YD3 ${ }^{\top}\left(={\text { KCTC } 22346^{\top}=\text { CCTCC AA208038 }}^{\top}\right)$ as the type strain.
\end{abstract}

The order Rhizobiales is a phenotypically heterogeneous assemblage within the $\alpha-2$ subgroup of the phylum Proteobacteria (Woese et al., 1984). The cluster includes members with a variety of morphological, physiological and biological features, which may impede their taxonomic definition (Lee et al., 2005). Garrity et al. (2004) proposed that the order Rhizobiales comprised 11 families based on 16S rRNA gene sequence analysis: Rhizobiaceae, 'Aurantimonadaceae', Bartonellaceae, Brucellaceae, Phyllobacteriaceae, Methylocystaceae, Beijerinckiaceae, Bradyrhizobiaceae, Hyphomicrobiaceae, Methylobacteriaceae and Rhodobiaceae. In addition to these families, a new family, Xanthobacteraceae (Lee et al., 2005), was described subsequently as a result of phylogenetic analysis of $16 \mathrm{~S}$

†These authors contributed equally to this work.

The GenBank/EMBL/DDBJ accession number for the 16S rRNA gene sequence of strain YIM YD3 ${ }^{\top}$ is EU878006.

An extended neighbour-joining phylogenetic tree showing the relationships between strain YIM YD3 ${ }^{\top}$ and most species in the order Rhizobiales with validly published names, is available with the online version of this paper.
rRNA gene sequences. Recently, another new family, Cohaesibacteraceae (type genus Cohaesibacter), within the order Rhizobiales was identified by Hwang \& Cho (2008) using a polyphasic approach. In this paper, characterization and classification of a novel genus-level strain within the order Rhizobiales is reported.

Strain YIM $\mathrm{YD}^{\mathrm{T}}$ was isolated from a deposit sample collected from a salt mine in Moxie, Yunnan Province, south-west China. The novel strain was isolated by the standard dilution-plating technique on marine agar 2216 (MA; Difco) cultivated in an anaerobic chamber (GasPak Anaerobic systems; BBL) at $28{ }^{\circ} \mathrm{C}$ for 14 days. Subsequently, the isolate was purified by cultivation on $\mathrm{MA}$ at $28{ }^{\circ} \mathrm{C}$ four times and then cultivated under aerobic or anaerobic conditions. The isolate was able to grow well under aerobic conditions. It was maintained on MA slants at $4{ }^{\circ} \mathrm{C}$ and stored as $20 \%$ glycerol suspensions at $-80{ }^{\circ} \mathrm{C}$.

Morphological, physiological and biochemical characteristics of strain YIM YD3 ${ }^{\mathrm{T}}$ were investigated using routine cultivation on MA. Gram staining was carried out using the standard Gram reaction combined with the $\mathrm{KOH}$ lysis 
test method (Gregersen, 1978). Cellular morphology and the presence of flagella were determined using light microscopy (BH-2; Olympus) after staining. Motility was determined by the hanging drop method (Smibert \& Krieg, 1994). Bacteriochlorophyll a production was analysed spectrophotometrically using the procedure of CohenBazire et al. (1957) following the recommendations of Allgaier et al. (2003). The presence of poly- $\beta$-hydroxybutyrate was determined by the Sudan Black B staining method (Smibert \& Krieg, 1994) under a light microscope. Thiosulfate oxidation was tested as described by Takeda et al. (2004). Growth was also tested on trypticase soy agar (TSA; BBL), nutrient agar and MY medium (Quesada et al., 1993). The temperature range $(5,10,15,20,28,30,35,37$ and $40{ }^{\circ} \mathrm{C}$ ) and $\mathrm{pH}$ range ( $\mathrm{pH} 4.0-10.0$ at unit intervals) for growth were tested on the basis of colony formation on MA plates. To test $\mathrm{NaCl}$ tolerance, TSA containing various concentrations of $\mathrm{NaCl}(0,0.5,1,2,3,5,7,10,15,20$ and $25 \%, w / v$ ) was used. Catalase activity was determined by assessing bubble production in $3 \%(\mathrm{v} / \mathrm{v}) \mathrm{H}_{2} \mathrm{O}_{2}$ and oxidase activity was determined using a $1 \%(\mathrm{w} / \mathrm{v})$ solution of tetramethyl-p-phenylenediamine (Kovacs, 1956). Degradation of aesculin, casein, starch, cellulose, Tweens 20, 40 and 60, xanthine and hypoxanthine was determined as described by Cowan \& Steel (1965). In addition, nitrate reduction, production of indole and $\mathrm{H}_{2} \mathrm{~S}$, arginine dihydrolase, lysine decarboxylase, ornithine decarboxylase, urease and gelatinase activities and the Voges-Proskauer test were assayed using API 20E and API 20NE kits (bioMérieux) according to the manufacturer's instructions, except that cell suspensions were supplemented with $3 \%$ $(\mathrm{w} / \mathrm{v}) \mathrm{NaCl}$. Other enzyme activities and acid production were assayed using the API ZYM and API $50 \mathrm{CH}$ kits (bioMérieux), respectively, with $3 \%(\mathrm{w} / \mathrm{v}) \mathrm{NaCl}$ solution as the suspension medium. Carbon utilization was tested using artificial seawater medium (Cho \& Giovannoni, 2006) as the basal medium containing each carbon source at a final concentration of $0.5 \%(\mathrm{w} / \mathrm{v}$ or $\mathrm{v} / \mathrm{v})$. Antibiotic sensitivities were determined using the disk-diffusion methodology (Bauer et al., 1966).

Polar lipids were extracted as described by Minnikin et al. (1979) and identified by two-dimensional TLC followed by spraying with specific reagents (Collins \& Jones, 1980). Respiratory quinones were extracted according to the method of Collins et al. (1977) and analysed by HPLC as described by Tamaoka et al. (1983). Biomass for quantitative fatty acid analysis of strain YIM YD ${ }^{\mathrm{T}}$ was obtained by scraping cells from MA that had been incubated for 5 days at $28{ }^{\circ} \mathrm{C}$. Analysis of the whole-cell fatty acid pattern followed the method of Sasser (1990) using the Microbial Identification system (MIDI). The genomic DNA G $+\mathrm{C}$ content was determined by HPLC according to Mesbah et al. (1989) after DNA extraction according to the method of Cui et al. (2001). Genomic DNA of Escherichia coli $\mathrm{H} 5 \alpha$ was used as a standard.

Genomic DNA extraction, PCR amplification of the $16 \mathrm{~S}$ rRNA gene and sequencing of the purified PCR products were carried out as described previously (Cui et al., 2001). The almost-complete 16S rRNA gene sequence of strain YIM YD3 $^{\mathrm{T}}$ (1412 bp) was obtained and compared with sequences available in GenBank/EMBL/DDBJ using BLAST searches (Altschul et al., 1990). The sequence of strain YIM $\mathrm{YD}^{\mathrm{T}}$ was aligned with those of 190 species with validly published names belonging to related families in the order Rhizobiales obtained from GenBank using the program CLUSTAL_X (Thompson et al., 1997). 16S rRNA gene sequence similarities were calculated using the program CLUSTAL_X. Phylogenetic trees were obtained by the neighbour-joining (Saitou \& Nei, 1987), maximumlikelihood (Felsenstein, 1981) and maximum-parsimony (Fitch, 1971) methods. An evolutionary distance matrix for the neighbour-joining method was generated according to Kimura's two-parameter model (Kimura, 1980). The robustness of tree topologies was assessed by bootstrap analyses based on 1000 replications for the neighbourjoining and maximum-parsimony methods.

Preliminary BLAST network searches in GenBank showed that the closest relative of strain YIM YD3 ${ }^{\mathrm{T}}$ was clone $69-29$ ( $98.1 \%$ sequence similarity), which was obtained from sediment of Guanting Reservoir (Qu et al., 2008). Sequence comparisons with representative bacteria with validly published names indicated that strain YIM YD3 ${ }^{\mathrm{T}}$ belonged to the class Alphaproteobacteria in the order Rhizobiales (Fig. 1; a global tree is available as Supplementary Fig. S1 in IJSEM Online). Strain YIM YD3 ${ }^{\mathrm{T}}$ formed a distinct phylogenetic lineage within a clade containing the genera Balneimonas, Bosea, Chelatococcus, Microvirga and Methylobacterium in the order Rhizobiales and was most closely related to the type strains of Balneimonas flocculans (93.5\% 16S rRNA gene sequence similarity), Chelatococcus daeguensis (93.0\%), Bosea massiliensis (92.6\%), Bosea minatitlanensis (92.5\%), Bosea eneae (92.3\%), Bosea vestrisii $(92.3 \%)$, Bosea thiooxidans (92.3\%), Chelatococcus asaccharovorans (92.2\%) and Microvirga subterranea (92.0\%). The 16S rRNA gene sequence similarity levels to the type strains of other type species in the order Rhizobiales were below $92.0 \%$. Therefore, the low sequence similarities between strain YIM YD3 ${ }^{\mathrm{T}}$ and its phylogenetic neighbours strongly indicate that strain YIM YD $3^{\mathrm{T}}$ is a member of a new genus in the order Rhizobiales.

Morphological, physiological and biochemical characteristics of strain YIM YD3 ${ }^{\mathrm{T}}$ are given in the genus and species descriptions and in Table 1. Major fatty acids of strain YIM $\mathrm{YD}^{\mathrm{T}}$ were $\mathrm{C}_{18: 1} \omega 7 c(39.80 \%), \mathrm{C}_{18: 1} \omega 9 c(13.27 \%), \mathrm{C}_{16: 0}$ $(13.15 \%), \mathrm{C}_{19: 0}$ cyclo $\omega 8 \mathrm{c}(12.07 \%), \mathrm{C}_{18: 0}(7.79 \%)$, summed feature 3 (iso- $\mathrm{C}_{15: 0} 2-\mathrm{OH}$ and/or $\mathrm{C}_{16: 1} \omega 7 c$; $2.44 \%)$, summed feature $5\left(\mathrm{C}_{18: 2} \omega 6,9 c\right.$ and/or anteiso$\left.\mathrm{C}_{18: 0} ; 2.36 \%\right), \mathrm{C}_{17: 0}$ cyclo $(1.80 \%)$ and $\mathrm{C}_{17: 0}(1.06 \%)$. Other minor fatty acids $(<1 \%)$ were $\mathrm{C}_{14: 0}, \mathrm{C}_{20: 1} \omega 9 c$, $\mathrm{C}_{18: 0} 3-\mathrm{OH}$, summed feature $2, \mathrm{C}_{20: 1} \omega 7 c, \mathrm{C}_{15: 0}, \mathrm{C}_{17: 1} \omega 8 c$, anteiso- $\mathrm{C}_{15: 0}$ and anteiso- $\mathrm{C}_{17: 0}$. Strain YIM $\mathrm{YD}^{\mathrm{T}}$ was Gram-negative and catalase- and oxidase-positive; these phenotypic properties were common to Balneimonas flocculans, C. daeguensis, Bosea massiliensis, Bosea mina- 


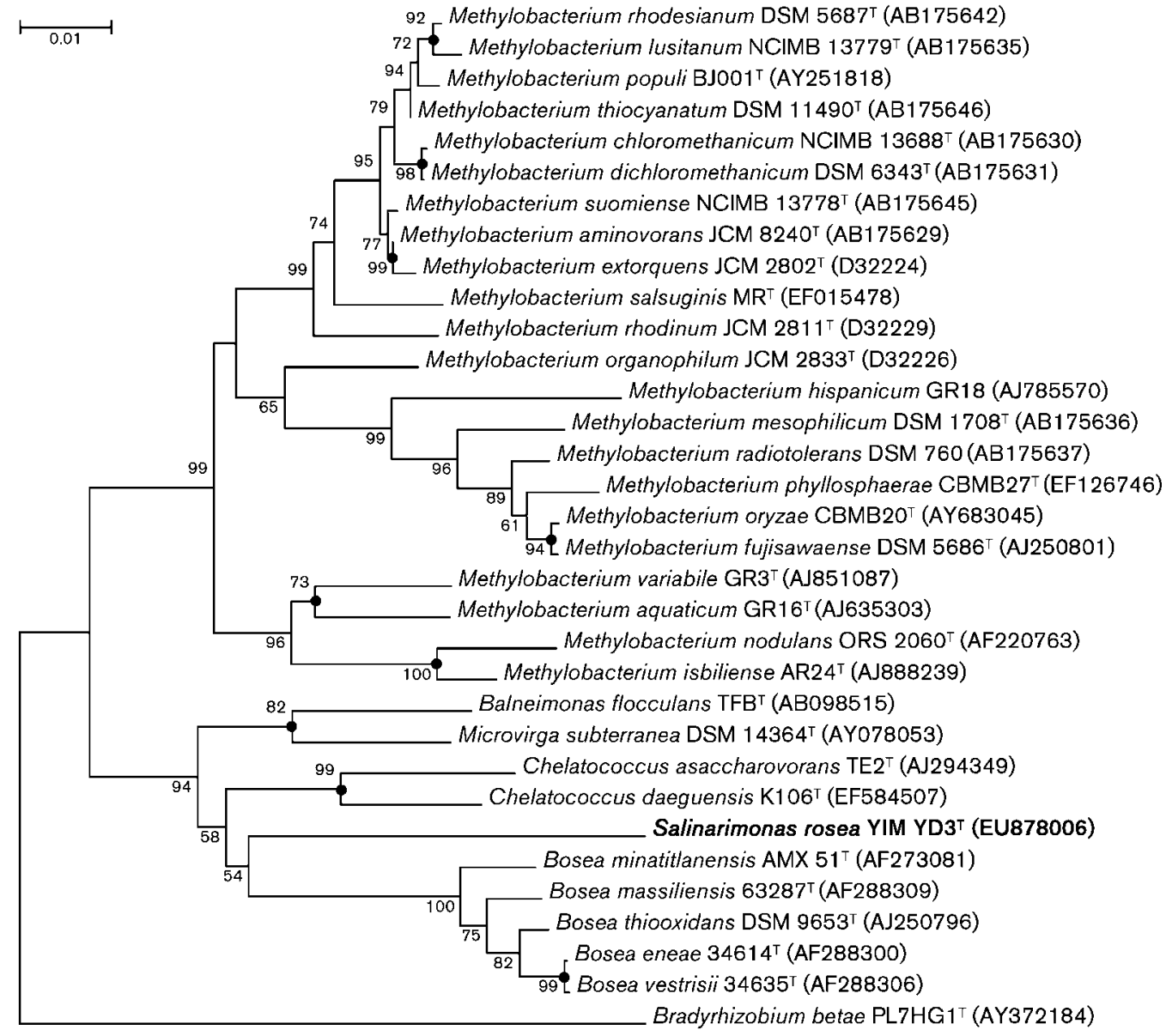

Fig. 1. Neighbour-joining phylogenetic tree based on $16 \mathrm{~S}$ rRNA gene sequences showing the positions of strain YIM YD3 ${ }^{\top}$ and some related taxa in the order Rhizobiales. Bradyrhizobium betae PL7HG $1^{\top}$ was used as the outgroup. Filled circles indicate that the corresponding nodes were also found in the trees generated with the maximum-likelihood and maximumparsimony algorithms. Bootstrap percentages (based on 1000 replications) $>50 \%$ are shown at branch points. Bar. 1 substitution per $100 \mathrm{nt}$ positions.

tiltanensis, Bosea eneae, Bosea vestrisii and C. asaccharovorans. However, numerous other properties of strain YIM $\mathrm{YD}^{\mathrm{T}}$ differed from those of these close phylogenetic relatives (Table 1). Strain YIM YD3 ${ }^{\mathrm{T}}$ could be differentiated from the type strain of Balneimonas flocculans based on the presence of $\mathrm{C}_{19: 0}$ cyclo $\omega 8 \mathrm{c}$ as the major fatty acid (Table 1). These two strains could also be distinguished by their differing abilities to reduce nitrate, produce urease, oxidize thiosulfate and produce acid from glucose, their different optimal growth temperatures (i.e. 28-30 for strain YIM YD3 ${ }^{\mathrm{T}}$ and $40-45{ }^{\circ} \mathrm{C}$ for Balneimonas flocculans) and utilization of glucose, maltose, D-xylose, fructose, sucrose, citrate and glycerol (Table 1; Takeda et al., 2004). In addition, the DNA $\mathrm{G}+\mathrm{C}$ content of strain YIM YD3 ${ }^{\mathrm{T}}$ (71.8 mol\%) was very different from that of Balneimonas flocculans $(64.0 \mathrm{~mol} \%)$. Strain YIM $\mathrm{YD}^{\mathrm{T}}$ could be distinguished from members of the genus Chelatococcus based on motility, optimal growth temperature (i.e. 28$30{ }^{\circ} \mathrm{C}$ for strain YIM YD3 ${ }^{\mathrm{T}}$ and $30-37{ }^{\circ} \mathrm{C}$ for members of the genus Chelatococcus) and utilization of maltose and sucrose (Table 1; Yoon et al., 2008). A comparison of polar lipids in strain YIM YD3 ${ }^{\mathrm{T}}$ and members of the genus Chelatococcus revealed an additional diphosphatidylglycerol in strain YIM YD3 ${ }^{\mathrm{T}}$, although phosphatidylcholine, phosphatidylglycerol, phosphatidylethanolamine and unknown phospholipids are commonly found in members of the genus Chelatococcus (Yoon et al., 2008). Another major difference in the polar lipid composition was the absence in strain YIM YD3 ${ }^{\mathrm{T}}$ of two aminolipids that are commonly found in members of the genus Chelatococcus (Yoon et al., 2008). Strain YIM YD3 ${ }^{\mathrm{T}}$ produced oxidase and urease and oxidized thiosulfate, but did not produce gelatinase, thus enabling it to be differentiated from Microvirga subterranea (Table 1; Kanso \& Patel, 2003); other differences included optimal growth temperature (i.e. $28-30{ }^{\circ} \mathrm{C}$ for strain YIM YD3 ${ }^{\mathrm{T}}$ and $41{ }^{\circ} \mathrm{C}$ for Microvirga subterranea) and utilization of glucose, sucrose, citrate and glycerol (Table 1; Kanso \& Patel, 2003). In addition, 
Table 1. Differential characteristics of strain $\mathrm{YIM} \mathrm{YD3}^{\top}$ and related strains

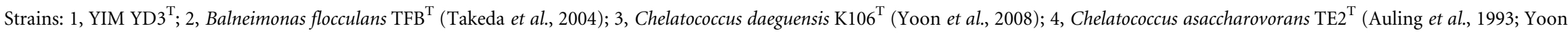
et al., 2008); 5, Bosea massiliensis $63287^{\mathrm{T}}$ (La Scola et al., 2003); 6, Bosea minatitlanensis AMX $51^{\mathrm{T}}$ (Ouattara et al., 2003); 7, Bosea eneae 34614 ${ }^{\mathrm{T}}$ (La Scola et al., 2003); 8, Bosea vestrisii 34635 ${ }^{\mathrm{T}}$ (La

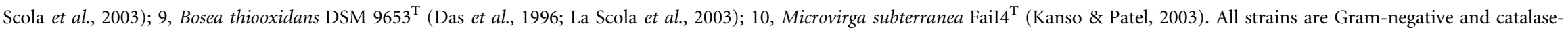
positive. +, Positive; -, negative; w, weakly positive; ND, no data.

\begin{tabular}{|c|c|c|c|c|c|c|c|c|c|c|}
\hline Characteristic & 1 & 2 & 3 & 4 & 5 & 6 & 7 & 8 & 9 & 10 \\
\hline Colony pigmentation & Pink & Absent & Yellow & White & Cream & Absent & Cream & Cream & Cream & Pink \\
\hline \multicolumn{11}{|l|}{ Cell morphology: } \\
\hline Shape & Rods & Rods & Rods & Diplococci & Rods & Rods & Rods & Rods & Rods & Rods \\
\hline Size $(\mu \mathrm{m})$ & $0.4-1.0 \times 1.20-1.45$ & $0.5-0.7 \times 1.5-3.5$ & $0.3-0.6 \times 1.0-4.0$ & $1.5-2.0 \times 1.2-1.5$ & $\mathrm{ND}$ & $0.5 \times 1.5-2.0$ & $\mathrm{ND}$ & $\mathrm{ND}$ & $0.83 \times 1.4-1.6$ & $1.0 \times 1.5-4.0$ \\
\hline Motility & + & + & - & - & + & + & + & + & + & + \\
\hline Flagella & Single polar & Single polar & Absent & Absent & Single polar & Single polar & Single polar & Single polar & Single polar & Single polar \\
\hline $\begin{array}{l}\text { Optimum growth } \\
\text { temperature }\left({ }^{\circ} \mathrm{C}\right)\end{array}$ & 28-30 & $40-45$ & $30-37$ & 36 & $25-37$ & 37 & $25-37$ & 25-37 & $30-32$ & 41 \\
\hline Optimum growth $\mathrm{pH}$ & $7.0-8.0$ & 7.0 & $7.0-7.5$ & $7.0-8.0$ & ND & 6.0 & ND & ND & $7.5-8.0$ & 7.0 \\
\hline Urease activity & + & - & - & + & + & + & + & + & - & - \\
\hline Nitrate reduction & + & - & + & + & + & - & - & - & + & + \\
\hline \multicolumn{11}{|l|}{ Growth on: } \\
\hline Glucose & + & - & + & + & - & - & - & + & + & - \\
\hline Maltose & + & - & - & - & + & - & - & + & + & $\mathrm{ND}$ \\
\hline D-Xylose & + & - & + & + & ND & - & ND & ND & + & + \\
\hline Fructose & + & - & + & - & $\mathrm{ND}$ & - & $\mathrm{ND}$ & $\mathrm{ND}$ & + & - \\
\hline Sucrose & + & - & - & - & ND & - & ND & ND & ND & - \\
\hline Citrate & + & - & + & - & - & - & - & + & + & - \\
\hline Glycerol & + & - & + & - & $\mathrm{ND}$ & $\mathrm{ND}$ & $\mathrm{ND}$ & $\mathrm{ND}$ & - & - \\
\hline \multicolumn{11}{|l|}{ Acid production from: } \\
\hline Arabinose & - & - & + & - & - & - & - & - & - & $\mathrm{w}$ \\
\hline Glucose & + & - & + & - & - & - & - & - & - & $\mathrm{w}$ \\
\hline Thiosulfate oxidation & + & - & ND & ND & - & + & - & - & + & - \\
\hline $\begin{array}{l}\text { Major fatty acids } \\
(>10 \% \text { of total fatty } \\
\text { acids })\end{array}$ & $\begin{array}{c}\mathrm{C}_{18: 1} \omega 7 c \\
\mathrm{C}_{18: 1} \omega 9 c, \mathrm{C}_{16: 0} \\
\mathrm{C}_{19: 0} \text { cyclo } \omega 8 c\end{array}$ & $C_{16: 0}, C_{18: 0}, C_{18: 1}$ & $\begin{array}{c}\mathrm{C}_{18: 1} \omega 7 c, \mathrm{C}_{19: 0} \\
\text { cyclo } \omega 8 c\end{array}$ & $\begin{array}{c}\mathrm{C}_{18: 1} \omega 7 c, \mathrm{C}_{19: 0} \\
\text { cyclo } \omega 8 c\end{array}$ & $\mathrm{C}_{18: 1} \omega 7 c$ & $\begin{array}{c}\mathrm{C}_{18: 1} \omega 7 c \\
\mathrm{C}_{19: 0} \text { cyclo } \\
\omega 8 c\end{array}$ & $\begin{array}{c}\mathrm{C}_{18: 1} \omega 7 c, \mathrm{C}_{19: 0} \\
\text { cyclo } \omega 8 c \\
\mathrm{C}_{16: 1} \omega 5 c\end{array}$ & $\begin{array}{c}\mathrm{C}_{18: 1} \omega 7 c \\
\mathrm{C}_{16: 1} \omega 7 c\end{array}$ & $\mathrm{C}_{18: 1} \omega 7 c$ & ND \\
\hline $\begin{array}{l}\text { DNA G + C content } \\
(\mathrm{mol} \%)\end{array}$ & 71.8 & 64.0 & 68.3 & 63 & 66.7 & $68.5 \pm 0.4$ & 69.0 & 65.0 & 68.2 & $63.5 \pm 0.5$ \\
\hline
\end{tabular}


combinations of phenotypic and chemotaxonomic characteristics could be used to differentiate strain YIM YD3 ${ }^{\mathrm{T}}$ from members of related genera in the order Rhizobiales. The results of the present study indicate that strain YIM $\mathrm{YD}^{\mathrm{T}}$ represents a novel species in a new genus, for which the name Salinarimonas rosea gen. nov., sp. nov. is proposed.

\section{Description of Salinarimonas gen. nov.}

Salinarimonas (Sa.li.na.ri.mo' nas. L. fem. pl. n. salinae arum salt works; L. fem. n. monas a monad, unit; N.L. fem. n. Salinarimonas a monad from salt works).

Facultatively anaerobic, rod-shaped cells. Gram-negative, motile and oxidase- and catalase-positive. Produces pinkpigmented colonies. The predominant fatty acids are $\mathrm{C}_{18: 1} \omega 7 c, \mathrm{C}_{18: 1} \omega 9 c, \mathrm{C}_{16: 0}$ and $\mathrm{C}_{19: 0}$ cyclo $\omega 8 c$. The predominant respiratory ubiquinone is $\mathrm{Q}-10$. The major polar lipids are diphosphatidylglycerol, phosphatidylglycerol, phosphatidylmethylethanolamine, phosphatidylcholine and two unknown phospholipids. The genus is a member of the order Rhizobiales. The type species is Salinarimonas rosea.

\section{Description of Salinarimonas rosea sp. nov.}

Salinarimonas rosea (ro'se.a. L. fem. adj. rosea rosecoloured, pink).

In addition to the characteristics reported for the genus, cells are halotolerant, motile by means of a single polar flagellum and approximately $0.4-1.0 \mu \mathrm{m}$ wide by 1.20 $1.45 \mu \mathrm{m}$ long. Growth occurs at $15-37{ }^{\circ} \mathrm{C}$ (optimum, 28 $30{ }^{\circ} \mathrm{C}$ ), at $\mathrm{pH}$ 6.0-9.0 (optimum, $\mathrm{pH} 7.0-8.0$ ) and in $\mathrm{NaCl}$ concentrations of $0-5 \%(\mathrm{w} / \mathrm{v})$ (optimum, $3 \%)$. Growth occurs on TSA, nutrient agar and MY medium. On MA or MY medium supplemented with $3 \%(\mathrm{w} / \mathrm{v}) \mathrm{NaCl}$, colonies are circular, entire, convex and pink in colour. After incubation for 5 days under optimal growth conditions, colonies are approximately $2.5 \mathrm{~mm}$ in diameter. Aesculin, xanthine and hypoxanthine are decomposed. Poly- $\beta$ hydroxybutyrate and bacteriochlorophyll $a$ are not detected. Positive for nitrate reduction, arginine dihydrolase, lysine decarboxylase, ornithine decarboxylase and urease, but negative for hydrolysis of gelatin and starch, and for production of indole and $\mathrm{H}_{2} \mathrm{~S}$. With the API ZYM kit, alkaline phosphatase, esterase (C4), esterase lipase (C8), lipase (C14), leucine arylamidase, valine arylamidase, cystine arylamidase, trypsin, $\alpha$-chymotrypsin, acid phosphatase and naphthol-AS-BI-phosphohydrolase are present, but $\alpha$ - and $\beta$-glucosidase, $\alpha$ - and $\beta$-galactosidase, $\beta$ glucuronidase, $N$-acetyl- $\beta$-glucosaminidase, $\alpha$-mannosidase and $\alpha$-fucosidase are absent. Acid is produced from glycerol, D-glucose, L-arabinose, D-ribose, DL-xylose, Dgalactose, D-fructose, D-mannose, maltose, sucrose, trehalose, raffinose, turanose, D-fucose and potassium 2ketogluconate. Utilizes acetate, citrate, D-fructose, Dglucose, D-mannose, ribose, D-xylose, sorbitol, glycerol, glycogen, inositol, inulin, L-arginine, L-asparagine, L-lysine, L-ornithine, pyruvate, sodium succinate, sucrose, Casamino acids, L-proline, peptone and tryptone as sole carbon sources, but does not utilize acetamide, benzoate, cellobiose, D-galactose, raffinose, salicin, trehalose, Lxylose, ethanol, L-rhamnose, maleic acid or tartrate. Cells are sensitive to ( $\mu \mathrm{g}$ per disc) amikacin (30), norfloxacin (10), ampicillin (10), cephalothin (30), benzylpenicillin (10), ciprofloxacin (5), carbenicillin (100), erythromycin (15) and chloramphenicol (30), but resistant to gentamicin (10). Major fatty acids are $\mathrm{C}_{18: 1} \omega 7 c, \mathrm{C}_{18: 1} \omega 9 c, \mathrm{C}_{16: 0}, \mathrm{C}_{19: 0}$ cyclo $\omega 8 c, \mathrm{C}_{18: 0}$, summed feature 3 (iso- $\mathrm{C}_{15: 0} 2-\mathrm{OH}$ and/ or $\left.\mathrm{C}_{16: 1} \omega 7 c\right)$, summed feature $5 \quad\left(\mathrm{C}_{18: 2} \omega 6,9 c\right.$ and/or anteiso- $\left.\mathrm{C}_{18: 0}\right), \mathrm{C}_{17: 0}$ cyclo and $\mathrm{C}_{17: 0}$; minor fatty acids are $\mathrm{C}_{14: 0}, \mathrm{C}_{20: 1} \omega 9 c, \mathrm{C}_{18: 0} 3-\mathrm{OH}$, summed feature 2 , $\mathrm{C}_{20: 1} \omega 7 c, \mathrm{C}_{15: 0}, \mathrm{C}_{17: 1} \omega 8 c$, anteiso- $\mathrm{C}_{15: 0}$ and anteiso$\mathrm{C}_{17: 0}$.

The type strain, YIM YD3 ${ }^{\mathrm{T}}\left(=\mathrm{KCTC} 22346^{\mathrm{T}}=\mathrm{CCTCC}\right.$ AA208038 ${ }^{\mathrm{T}}$ ), was isolated from a deposit from a salt mine in Yunnan, China. The DNA G $+\mathrm{C}$ content of the type strain is $71.8 \mathrm{~mol} \%$.

\section{Acknowledgements}

This work was supported by grants from the National Natural Science Foundation of China (NSFC; 30860013, 30460004, 30660004 and 30760006), the Ministry of Science and Technology of China (863 Program nos 2007AA021306 and 2006BAE01A01-9), the Yunnan Provincial Sciences and Technology Department (2005PY01-1, 2009CD012 and 2009DA002) and Yunnan University (2008YB005). We are grateful to Mr Wei Chen for his help during sampling and to Professor Dr Hans G. Trüper for recommending the proper etymology.

\section{References}

Allgaier, M., Uphoff, H., Felske, A. \& Wagner-Döbler, I. (2003). Aerobic anoxygenic photosynthesis in Roseobacter clade bacteria from diverse marine habitats. Appl Environ Microbiol 69, 50515059.

Altschul, S. F., Gish, W., Miller, W., Myers, E. W. \& Lipman, D. J. (1990). Basic local alignment search tool. J Mol Biol 215, 403-410.

Auling, G., Busse, H.-J., Egli, T., El-Banna, T. \& Stackebrandt, E. (1993). Description of the gram-negative, obligately aerobic, nitrilotriacetate (NTA)-utilizing bacteria as Chelatobacter heintzii, gen. nov., sp. nov., and Chelatococcus asaccharovorans, gen. nov., sp. nov. Syst Appl Microbiol 16, 104-112.

Bauer, A. W., Kirby, W. M. M., Sherris, J. C. \& Turck, M. (1966). Antibiotic susceptibility testing by a standardized single disk method. Am J Clin Pathol 45, 493-496.

Cho, J. C. \& Giovannoni, S. J. (2006). Pelagibaca bermudensis gen. nov., sp. nov., a novel marine bacterium within the Roseobacter clade in the order Rhodobacterales. Int J Syst Evol Microbiol 56, 855859.

Cohen-Bazire, G., Sistrom, W. R. \& Stanier, R. Y. (1957). Kinetic studies of pigment synthesis by nonsulfur purple bacteria. J Cell Comp Physiol 49, 25-68.

Collins, M. D. \& Jones, D. (1980). Lipids in the classification and identification of coryneform bacteria containing peptidoglycans based on 2,4-diaminobutyric acid. J Appl Bacteriol 48, 459-470. 
Collins, M. D., Pirouz, T., Goodfellow, M. \& Minnikin, D. E. (1977). Distribution of menaquinones in actinomycetes and corynebacteria. J Gen Microbiol 100, 221-230.

Cowan, S. T. \& Steel, K. J. (1965). Manual for the Identification of Medical Bacteria. London: Cambridge University Press.

Cui, X. L., Mao, P. H., Zeng, M., Li, W. J., Zhang, L. P., Xu, L. H. \& Jiang, C. L. (2001). Streptimonospora salina gen. nov., sp. nov., a new member of the family Nocardiopsaceae. Int J Syst Evol Microbiol 51, 357-363.

Das, S. K., Mishra, A. K., Tindall, B. J., Rainey, F. A. \& Stackebrandt, E. (1996). Oxidation of thiosulfate by a new bacterium, Bosea thiooxidans (strain BI-42) gen. nov., sp. nov.: analysis of phylogeny based on chemotaxonomy and $16 \mathrm{~S}$ ribosomal DNA sequencing. Int $J$ Syst Bacteriol 46, 981-987.

Felsenstein, J. (1981). Evolutionary trees from DNA sequences: a maximum likelihood approach. J Mol Evol 17, 368-376.

Fitch, W. M. (1971). Toward defining the course of evolution: minimum change for a specific tree topology. Syst Zool 20, 406-416.

Garrity, G. M., Bell, J. A. \& Lilburn, T. G. (2004). Taxonomic outline of the prokaryotes. In Bergey's Manual of Systematic Bacteriology, 2nd edn, release 5.0. New York: Springer. http://www.bergeys.org/outlines/bergeysoutline_5_2004.pdf

Gregersen, T. (1978). Rapid method for distinction of Gram-negative from Gram-positive bacteria. Eur J Appl Microbiol Biotechnol 5, 123-127.

Hwang, C. Y. \& Cho, B. C. (2008). Cohaesibacter gelatinilyticus gen. nov., sp. nov., a marine bacterium that forms a distinct branch in the order Rhizobiales, and proposal of Cohaesibacteraceae fam. nov. Int $J$ Syst Evol Microbiol 58, 267-277.

Kanso, S. W. \& Patel, B. K. C. (2003). Microvirga subterranea gen. nov., sp. nov., a moderate thermophile from a deep subsurface Australian thermal aquifer. Int J Syst Evol Microbiol 53, 401-406.

Kimura, M. (1980). A simple method for estimating evolutionary rates of base substitutions through comparative studies of nucleotide sequences. J Mol Evol 16, 111-120.

Kovacs, N. (1956). Identification of Pseudomonas pyocyanea by oxidase reaction. Nature 178, 703 .

La Scola, B., Mallet, M. N., Grimont, P. A. D. \& Raoult, D. (2003). Bodea eneae sp. nov., Bosea massiliensis sp. nov. and Bosea vestrisii sp. nov., isolated from hospital water supplies, and emendation of the genus Bosea (Das et al. 1996). Int J Syst Evol Microbiol 53, 15-20.

Lee, K. B., Liu, C. T., Anzai, Y., Kim, H., Aono, T. \& Oyaizu, H. (2005). The hierarchical system of the 'Alphaproteobacteria': description of Hyphomonadaceae fam. nov., Xanthobacteraceae fam. nov. and Erythrobacteraceae fam. nov. Int J Syst Evol Microbiol 55, 1907-1919.
Mesbah, M., Premachandran, U. \& Whitman, W. B. (1989). Precise measurement of the $\mathrm{G}+\mathrm{C}$ content of deoxyribonucleic acid by high-performance liquid chromatography. Int J Syst Bacteriol 39, 159167.

Minnikin, D. E., Collins, M. D. \& Goodfellow, M. (1979). Fatty acid and polar lipid composition in the classification of Cellulomonas, Oerskovia and related taxa. J Appl Microbiol 47, 87-95.

Ouattara, A. S., Assih, E. A., Thierry, S., Cayol, J. L., Labat, M., Monroy, O. \& Macarie, H. (2003). Bosea minatitlanensis sp. nov., a strictly aerobic bacterium isolated from an anaerobic digester. Int $J$ Syst Evol Microbiol 53, 1247-1251.

Qu, J. H., Yuan, H. L., Wang, E. T., Li, C. \& Huang, H. Z. (2008). Bacterial diversity in sediments of the eutrophic Guanting Reservoir, China, estimated by analyses of $16 \mathrm{~S}$ rDNA sequence. Biodivers Conserv 17, 1667-1683.

Quesada, E., Béjar, V. \& Calvo, C. (1993). Exopolysaccharide production by Volcaniella eurihalina. Experientia 49, 1037-1041.

Saitou, N. \& Nei, M. (1987). The neighbor-joining method: a new method for reconstructing phylogenetic trees. Mol Biol Evol 4, 406425.

Sasser, M. (1990). Identification of bacteria by gas chromatography of cellular fatty acids. USFCC Newsl 20, 16.

Smibert, R. M. \& Krieg, N. R. (1994). Phenotypic characterization. In Methods for General and Molecular Bacteriology, pp. 607-654. Edited by P. Gerhardt, R. G. E. Murray, W. A. Wood \& N. R. Krieg. Washington, DC: American Society for Microbiology.

Takeda, M., Suzuki, I. \& Koizumi, J. (2004). Balneomonas flocculans gen. nov., sp. nov., a new cellulose-producing member of the $\alpha-2$ subclass of Proteobacteria. Syst Appl Microbiol 27, 139-145.

Tamaoka, J., Katayama-Fujimura, Y. \& Kuraishi, H. (1983). Analysis of bacterial menaquinone mixtures by high performance liquid chromatography. J Appl Microbiol 54, 31-36.

Thompson, J. D., Gibson, T. J., Plewniak, F., Jeanmougin, F. \& Higgins, D. G. (1997). The CLUSTAL_X windows interface: flexible strategies for multiple sequence alignment aided by quality analysis tools. Nucleic Acids Res 25, 4876-4882.

Woese, C. R., Stackebrandt, E., Weisburg, W. G., Paster, B. J., Madigan, M. T., Fowler, V. J., Hahn, C. M., Blanz, P., Gupta, R. \& other authors (1984). The phylogeny of purple bacteria: the alpha subdivision. Syst Appl Microbiol 5, 315-326.

Yoon, J.-H., Kang, S.-J., Im, W.-T., Lee, S.-T. \& Oh, T.-K. (2008). Chelatococcus daeguensis sp. nov., isolated from wastewater of a textile dye works, and emended description of the genus Chelatococcus. Int $J$ Syst Evol Microbiol 58, 2224-2228. 